\title{
Civicness: From Civil Society to Civic Services?
}

\author{
Paul Dekker
}

Published online: 9 July 2009

(C) The Author(s) 2009. This article is published with open access at Springerlink.com

\begin{abstract}
Activities in civil society, seen as the sphere of society in which voluntary associations are dominant, are considered an important source of civility in modern society. By interacting and finding solutions for common problems, members of associations turn into citizens with a broader perspective and interest in the common good. The evidence for these positive roles is at best mixed, however. Not voluntarily associating in a separate sphere of civil society, but combining associational with public and commercial modes of social coordination, appears to offer a more promising option for civilizing modern society. Examples of hybridity are discussed. The paper concludes with a plea for a clearer recognition in social research of civicness as a normative perspective.
\end{abstract}

Résumé Les activités dans la société civile, vue comme la sphère de la société dans laquelle les associations caritatives sont dominantes, prennent en compte une source importante de courtoisie dans la société moderne. En communicant et en trouvant des solutions à des problèmes courants, les membres d'associations deviennent citoyens dotés d'un point de vue et d'un intérêt plus larges pour le bien commun. Cependant, la preuve de ces rôles positifs est au mieux partagée. Ne s'associant pas volontairement dans une sphère séparée de la société civile, mais combinant l'associatif avec les modes public et commercial de la coordination sociale, elle apparaît offrir une option plus prometteuse pour la société citoyenne moderne. Des exemples d'hybridité sont discutés. L'article conclut par un appel à une reconnaissance plus claire dans la recherche sociale de civisme dans une optique normative.

P. Dekker $(\bowtie)$

Tilburg University and The Netherlands Institute for Social Research/SCP,

Postbus 16164, 2500 BD Den Haag, The Netherlands

e-mail: p.dekker@scp.nl 
Zusammenfassung Aktivitäten in der Zivilgesellschaft, gesehen als die Sphäre der Gesellschaft, in der freiwillige Vereinigungen dominieren, werden als eine bedeutende Quelle von Zivilität in der modernen Gesellschaft angesehen. Indem sie interagieren und Lösungen für häufig auftretende Probleme finden, verwandeln sich Mitglieder von Vereinigungen in Staatsbürger mit einer breiteren Perspektive und Interesse am Allgemeinwohl. Allerdings sind Beweise für diese positiven Rollen bestenfalls uneinheitlich. Keine freiwillige Vereinigung in einer separaten Sphäre der Zivilgesellschaft, aber vereinigende Formen mit öffentlichen und kommerziellen Formen von sozialer Koordinierung zu kombinieren, scheint eine erfolgversprechendere Alternative zur Zivilisierung der modernen Gesellschaft zu bieten. Beispiele von Hybridität werden diskutiert. Der Artikel endet mit einem Appell für eine klarere Anerkennung von civicness als eine normative Perspektive in der Sozialforschung.

Resumen Las actividades de la sociedad civil, la esfera de la sociedad donde predominan las asociaciones voluntarias, se consideran una importante fuente de civilidad para la sociedad moderna. Interactuando y encontrando soluciones para los problemas comunes, los miembros de las asociaciones se convierten en ciudadanos con una perspectiva y un interés más amplios en el bien común. Sin embargo, las pruebas de esos papeles positivos están, a lo sumo, mezcladas. No asociarse voluntariamente en una esfera distinta de la sociedad civil, sino combinando la asociación con los modos públicos y comerciales de la coordinación social, parece ofrecer una opción más prometedora para la sociedad civil moderna. Se analizan ejemplos de híbridos. El trabajo concluye con un llamamiento a un reconocimiento más claro en los estudios sociales de la civilidad como perspectiva normativa.

Keywords Civicness - Civil society - Civility - Voluntary associations · Hybrid organizations · Normative theory

\section{Introduction}

Civility and citizenship: two words which are etymologically strongly linked and two phenomena which are both said to be in decline. The spontaneous associations they invoke, however, can be quite contradictory: duties versus rights; politeness versus politics; passive acceptance versus active involvement; a preoccupation of conservatives versus a mania of progressives. On further reflection, civility and citizenship turn out to produce similar ambivalences. From the common civicness perspective of this special issue, I will place civility in the spotlight and bring in citizenship only when some concrete embodiment is called for. Following a discussion of the concept of civility, this paper will focus on the expected civilizing effects of civil society and the evidence for this in empirical research. The results, it will be seen, are not very convincing, and attention is directed to more fragmented and qualitative evidence for civicness in hybrid organizations, in which elements of voluntary involvement are combined with input from government and business. The 
paper concludes with a brief discussion of the desirability of the explicit acknowledgement of civicness as a normative perspective in social research.

\section{Civility}

In the introductory paper, we defined civicness as the capacity of institutions, organizations, and procedures to stimulate, reproduce, and cultivate civility. What is civility? According to the Collins Essential English Dictionary (2nd edition, 2006) "civility" means "politeness, consideration, courtesy, tact, good manners, graciousness, cordiality, affability, amiability, complaisance, courteousness." ${ }^{1}$ In daily life, civility is mostly associated with virtues and individual manners. People demonstrate civility when they hold back in the pursuit of their own self-interest; are polite and helpful to other people, but on the other hand perhaps a little aloof; when they show an interest in public affairs but without being too fanatical; and so on. People show no civility when they behave selfishly and aggressively, do not know how to behave in public (i.e., behave as if they were at home), and are completely indifferent to issues of communal and public interest.

These meanings in ordinary life are reflected in the philosophical and social science literature, cropping up in various guises and often accentuating a perspective of common interest and a relationship with public controversies and democratic politics.

Edward Shils, to quote one of the most prominent thinkers on civility, draws a distinction between "normal" and "substantive" civility:

The term "civility" has usually, both in the past and in its recent revival, been interpreted to mean courtesy, well-spokenness, moderation, respect for others, self-restraint, gentlemanliness, urbanity, refinement, good manners, politeness... Substantive civility is the virtue of civil society. It is the readiness to moderate particular, individual or parochial interests and to give precedence to the common good. The common good is not susceptible to an unambiguous definition; consensus about it is probably not attainable. It is however certainly meaningful to speak about it. Wherever two antagonistic advocates arrive at a compromise through recognition of a common interest, they redefine themselves as members of a collectivity, the good of which has precedence over their own particular objectives. (Shils 1997, pp. 337-338, 345)

Civility is of particular importance in public spaces, regarding relations between people who might not know each other. Boyd (2006) describes civility as a way of

\footnotetext{
1 According to the same dictionary the adjective "civil" has more diverse meanings than the noun "civility." Civil refers to "1. of or occurring within the state or between citizens: civil unrest; 2. of or relating to the citizen as an individual: civil rights; 3 . not part of the military, legal or religious structures of a country: civil aviation; 4. polite or courteous: he seemed very civil and listened politely." The noun associated with civil, i.e., the state or quality of being civil, is not civility but the unusual term "civilness." "Civil" and "civic" seem to be more or less synonymous, and for a non-native speaker it is sometimes difficult to understand when which term is used. It is civic action but civil obedience, civil society but civic culture and civic community, civil rights but civic duties, and there is both a civil service (the public servants) and a civic service (the alternative to military service).
} 
coping with diversity. Carter (1998, p. 242) sees it as "an ethic for strangers"; it is a moral duty, not dependent on liking the other person.

The aspects of respect and courtesy or politeness, and self-restraint and moderation, are mentioned by many authors (Banfield 1992; Billante and Saunders 2002; Sistare 2004; White 2006), not only as conditions for interpersonal and intergroup relationships, but also as conditions for political democracy and a democratic culture in society. Civility is necessary for mutual understanding, searching for common interests, and finding compromises between citizens, and is required when agreement cannot be reached and people have to continue living with their conflicting interests and different views on the common good. By supporting self-regulation and preventing social clashes, civility can help to obviate the need for state intervention.

Various authors stress more active and assertive values as part of civility. The inherent respect for others or beliefs about the common good suggests that civility could imply a duty to go against common sense or state policies. Civility "values diversity, disagreement, and the possibility of resistance" (Carter 1998, p. 242). "Civility is not about politeness; it is about responsibility, which is why disobedience can also be civil" (Barber 1998, p. 122) - a quote that already hints at some of the tensions and ambivalences of civility. It implies general norms of good conduct for everybody, but also refers to courtly distinction; it should be allinclusive and yet it is used to exclude (White 2006). It calls for social conformity and acceptance as well as civic courage. It embraces a focus on common interests yet requires "agreement only on means and not on ends" (Hayek, quoted in Boyd 2006, p. 871). People should be tolerant and ready to revise their opinions, but also self-confident enough to engage in controversies and politics. The tolerance side of civility undercuts the commitment to active citizenship and encourages passivity (Mouritsen 2003; Walzer 1974). ${ }^{2}$

Conservatives and progressives, communitarians and liberals, will take different positions on these issues, and there are shifts over time and differences between cultures as regards the priorities. ${ }^{3}$ This makes the notion of civility itself an issue of social and political controversies. It can be translated both into respect for the powerful and into a desire to draw attention to the plight of the powerless. "Civility" can be used equally well as an argument for demanding equal rights and as an argument for declaring the associated claiming activities to be unfit.

Although meanings differ, civility primarily-or exclusively-concerns the attitudes and behaviour of individuals. In this paper, we follow this focus on the civility of individuals. We are interested in how larger entities influence this civility

\footnotetext{
${ }^{2}$ Empirical evidence has been found for a kind of trade-off between the two by Mutz (2006): in more diverse groups tolerance and mutual understanding may rise, but the ability to act collectively may decrease.

${ }^{3}$ See the "civic culture" of Almond and Verba (1989). The book, The civic culture, first published in 1963, compares national political cultures with different priorities and develops civic culture as a combination of subject and activist orientations. See Pye (1999) for an intriguing comparison of civility in several Asian cultures. Pye analyses different pattern of general norms of personal interaction in intimate relations and public relationships, as regards superior-inferior relationships, and to control human aggression and manage conflict situations: "The practices of a society in these three areas have significant consequences in facilitating or retarding democratic development" (Pye 1999, p. 766).
} 
(in their "civicness"), but we do not address the civility of communities, institutions, or societies. ${ }^{4}$

Before turning to the civicness of civil society in the next section, we will take a brief last look at civility from a different angle here. The "experts" see civility as a mix of politeness, tolerance, care for others, common interests, and a readiness to protest. What, however, about the objects of these reflections? How do citizens themselves think they should behave? There appears to be no large-scale research on people's ideas about civility, but in various surveys people have been asked about good citizenship (Dekker 2008). Table 1 presents results from the 2004 citizenship module of the International Social Survey Programme (ISSP) for 12 countries worldwide. ${ }^{5}$ For each country, the most important feature is underscored. The table shows that people in different parts of the world differ in their ideas about what constitutes good citizenship; obeying laws and regulations scores well above average everywhere, while being active in social and political associations scores far below average. Environmental activities and international solidarity (in the latter case with the exception of Brazil and Mexico) are also not regarded as great civic virtues by most people.

Similar questions in European surveys also show a high priority given to obeying laws, in addition to helping other people and forming one's opinions independently of others. Voting in elections is also recognized as an important trait of good citizens, but being active in politics and in voluntary associations is seen as the least important in all European countries surveyed. These surveys use closed questions with response options that reflect the interests and presumptions of social scientists; what happens to perceptions of good citizenship if we ask about it in a more open way?

We have done this in The Netherlands, by asking people in surveys held in 1996 and 2004 to sum up in no more than five points each what "a good citizen" does and what (s)he does not do (Dekker 2008). The answers can be categorized and combined in many ways, but evidently politics is even less important than when measured using closed questions. If people are asked about voting, they may confirm the moral duty to vote, but are less likely to come up with the notion of voting without being prompted. The most important aspects that come out of these surveys are being a social person: not being a burden to other people, having a positive attitude (tolerance, understanding), and doing good to others. People mention volunteering, more in the informal sense of helping others than in a formal sense of doing things for or in organizations. Besides this social side to good citizenship, there is the side of obeying the law, not driving too fast, not committing crimes, and so on. It would seem that people see things more in terms of what a good citizen does not than what he or she does do. Some people mention that a good

\footnotetext{
4 A related idea is the "decent society" of Avishai Margalit who sees it as part of the more ambitious idea of a just society and distinguishes it from a civilized one: "A civilized society is one whose members do not humiliate one another, while a decent society is one in which the institutions do not humiliate people" (Margalit 1996, p. 1).

5 People were asked how important they felt ten characteristics were to being a good citizen. I leave out the feature "to be willing to serve in the military at a time of need," because national regulations on this topic differ. I have selected countries from various continents, but have no data for African countries.
} 
Table 1 The relative importance of nine features of a good citizen in twelve countries worldwide ${ }^{\mathrm{a}}$

\begin{tabular}{|c|c|c|c|c|c|c|c|c|c|c|c|c|}
\hline & BR & MX & US & $\mathrm{AU}$ & JP & KR & RU & $\mathrm{CZ}$ & BG & PT & NL & SE \\
\hline $\begin{array}{l}\text { Always to obey laws and } \\
\text { regulations }\end{array}$ & 8 & 10 & 13 & 13 & 18 & 13 & $\underline{18}$ & $\underline{20}$ & $\underline{27}$ & $\underline{8}$ & 8 & 11 \\
\hline Never to evade taxes & 1 & 3 & 11 & 9 & $\underline{19}$ & $\underline{14}$ & 15 & 17 & 22 & 7 & 4 & 7 \\
\hline Always to vote in elections & 1 & 4 & 8 & 9 & 9 & 10 & 8 & 0 & 5 & 2 & 8 & $\underline{17}$ \\
\hline $\begin{array}{l}\text { To try to understand the } \\
\text { reasoning of people with } \\
\text { other opinions }\end{array}$ & 2 & 5 & 2 & 4 & 0 & 4 & 5 & 5 & 8 & 2 & 11 & 8 \\
\hline $\begin{array}{l}\text { To help people in [your } \\
\text { country] who are worse off } \\
\text { than yourself }\end{array}$ & $\underline{14}$ & $\underline{11}$ & 5 & 3 & -3 & 0 & 3 & 2 & 7 & 5 & 3 & -3 \\
\hline $\begin{array}{l}\text { To keep an eye on the actions } \\
\text { of government }\end{array}$ & 1 & 1 & 7 & 7 & 6 & 2 & 1 & -7 & -10 & -1 & 6 & 11 \\
\hline $\begin{array}{l}\text { To help people in the rest of } \\
\text { the world who are worse off } \\
\text { than yourself }\end{array}$ & 10 & 8 & -14 & -12 & -11 & -23 & -16 & -5 & -2 & -1 & -3 & -8 \\
\hline $\begin{array}{l}\text { To choose products for } \\
\text { political, ethical or } \\
\text { environmental reasons, even } \\
\text { if they cost a bit more }\end{array}$ & -21 & -29 & -15 & -9 & -15 & -4 & -18 & -14 & -35 & -4 & -17 & -12 \\
\hline $\begin{array}{l}\text { To be active in social and } \\
\text { political associations }\end{array}$ & -16 & -14 & -18 & -23 & -22 & -15 & -14 & -19 & -22 & -17 & -21 & -30 \\
\hline
\end{tabular}

Source: ISSP citizenship module (2004/5), population aged 18 and older, weighted results

Country codes: BR Brazil, MX Mexico, US United States, AU Australia, JP Japan, KR South Korea, $R U$ Russia, $C Z$ Czech Republic, $B G$ Bulgaria, $P T$ Portugal, $N L$ Netherlands, SE Sweden

a Deviations from the national average for all nine traits on a scale from 0 (not at all important) to 100 (very important) replying to the question: "There are different opinions on what it takes to be a good citizen. As far as you are concerned personally... how important is it ...?"

citizen treats his or her children well, does not beat his wife, etc., but these are exceptions. The large majority of respondents say nothing either about pure politics or about the intimate sphere, but talk instead about attitudes and behaviour in the more or less public space in between. They seem to focus largely on civic virtues, on responsibilities towards other people and the community.

Active political involvement does not form part of the public understanding of good citizenship (cf. Theiss-Morse and Hibbing 2005; Wuthnow 1998). We will nonetheless consider this to be an important element of civility when we lookbelow - at the civicness, the civilizing effects, of civil society.

\section{The Expected Civicness of Civil Society}

Definitions of civil society range from large numbers of descriptions of a societal sphere lying somewhere between economy, state, and intimate private life, and of identifications of civil-society organizations based on some characteristic way of operating or functioning (being nonprofit, based on voluntariness and arguments, 
active in the public sphere, developing solidarity), to a smaller number of definitions which describe entire societies as civil. ${ }^{6}$ Different meanings are also often conflated (Edwards 2004, p. 10), especially in simplistic suggestions that a vibrant sector of voluntary associations is the infrastructure of a democratic public sphere and a condition, or at least a boost, for civil society in the sense of a civilized (entire) society.

Not being part of the state is central to the notion of civil society as a societal sphere. The demarcation with regard to the market (or business, or the economy) and the intimate private sphere is less clear. There may well be sound historical and political reasons for defining civil society as everything that is the opposite of an oppressive state, or as almost everything that falls outside a dominant market and opposes commercialization, but in highly differentiated Western societies the civil society sphere occupies a more complex in-between position.

Rather than being defined as non-state, non-market, and non-family, civil society can also be described in a positive sense as the societal domain within which voluntary associations and associative relations are dominant. ${ }^{7}$ There are no clearcut criteria for deciding which associations should be included, that are currently situated in that grey area somewhere between civil society and the other realms. Given the importance of voluntariness in our conception of civil society, associations which one "grows up in," or from which one can only extract oneself at considerable cost, or that hold a monopoly in a given domain, fail to qualify as typical civil-society organizations. However, because of their strong relationships with real voluntary associations and because they have similar functions and positions in society, they can belong to civil society as a societal domain. The focus on a particular domain or sphere of society goes against operational definitions of civil society as a tool for classifying single organizations and deciding whether the Catholic Church, monopolistic trade unions, or the Ku Klux Klan are "in" or "out." In particular, it goes against the use of normative criteria such as "civility" as a condition for inclusion. Research on the role of organizations in a real civil society should not be confused with their acceptance as part of a good civil society. ${ }^{8}$

The thesis that a flourishing sphere of civil society is the carrier of the ideal of civil society as a civilized society can inspire research and has a long history. The

\footnotetext{
${ }^{6}$ For instance, Edwards Shils (1997, p. 322) described civil society as "a society of civility in the conduct of the members of the society towards each other."

7 Cf. Warren (2001) who puts "pure associative relations" at the heart of civil society, besides states with power and markets with money. Associative relations are based on normative and discursive influence. They can be found everywhere in society in combination with the other means of social coordination, but are most purely found in voluntary associations.

${ }^{8}$ It is a restrictive to include "civility" in definitions of civil society that are meant to identify parts of social reality for empirical research. Anheier (2007, p. 11) adds "based on civility" to his definition of global civil society to exclude, among others, violent activists and hate groups. The risk, here, is that political controversies between researchers about the applicability of the negative adverbs may replace investigations into controversies in the field of research, the combinations of civil and uncivil elements in organizations and networks of organizations, trends, etc. Alexander's (2006) almost teleological concept of a "civil sphere" with intrinsic universalizing values of solidarity, equality, and democracy, seems to be more a framework for interpreting contradictory developments than a tool for identifying good and bad organizations, but it would run the same risk if used in an operational way for empirical research.
} 
thinking about civil society has always been characterized by the double reference to existing social relations and societal ideals (cf. Dekker 2004).

The modern idea of civil society has developed since the second half of the seventeenth century, initially as a means of registering and seeking to reduce the power of absolute rulers in favour of the freedom, self-regulating power, and political influence of emerging bourgeois society. ${ }^{9}$ With the rise of the capitalist market economy, the economy came to operate in an autonomous sphere far removed from social relations and governed amorally by self-interest. The polarity of state versus society developed into a more complex situation where the ideal and practice of civil society was opposed to both the state and the market. The economy and capitalist system became more important as drivers of activities of voluntary associations, but in a different sphere. For individuals this meant combining being a private bourgeois (or working) person with being a more public citizen, connected to politics as an individual and connected to politics and society as a member of associations. Civil society became a specific sphere of voluntary involvement for the benefit of small-scale common interests and pleasures as well as for society as a whole. In the second half of the twentieth century, this sphere of civil society also developed in opposition to the private and intimate sphere, where people retire from social obligations and public life. After the absolute ruler and the homo economicus, the indifferent private person was now the threat to civility and civil society.

Figure 1 portrays the polarities of the sphere of civil society versus state, market, and community. The polarities imply aspects of civility in the broad sense used earlier: decent behaviour against the intimate and group-specific behaviour of community, and against the instrumentality of economic transactions; and democratic involvement against the state.

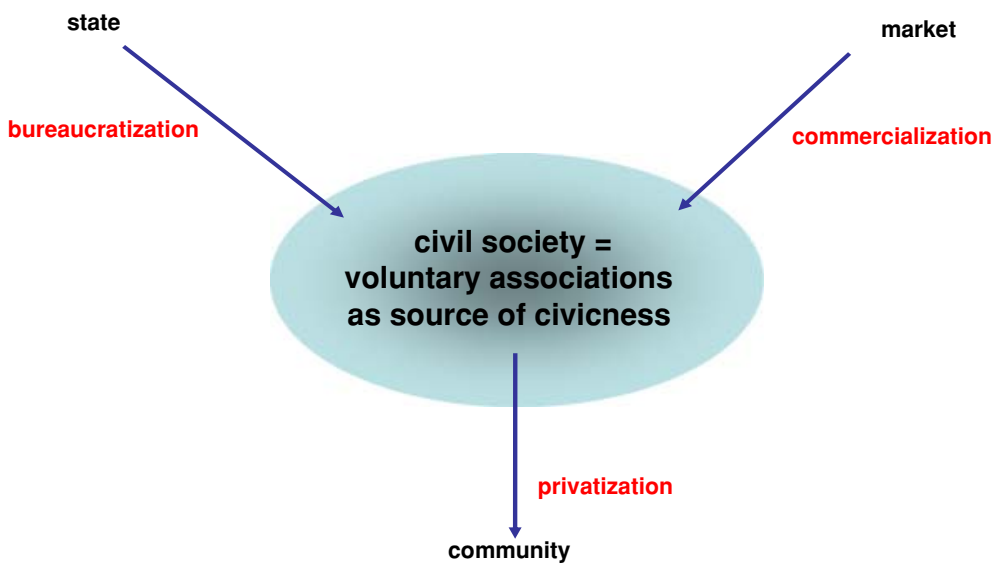

Fig. 1 The old debate: Civil society and civicness threatened and betrayed

\footnotetext{
9 See among many other publications the beautifully short chapter by Taylor (2003), the more polemic book by Keane (1998), or the long treatises by Cohen and Arato (1992) and Alexander (2006) for more serious historical accounts of the concept of civil society.
} 
Why do we expect civicness to ensue from participation in the civil society sphere? It is basically because voluntary associations are supposed to bring people together, especially citizens from different social groups, to connect them, generate trust, and stimulate discussions; organizations are supposed to connect to broader networks, influence the political agenda, and hold government accountable. As regards the public discourse, much of the research focuses on the relationships between participation (membership or volunteering) in non-political voluntary associations and political involvement. In the literature several reasons are discussed as to why participation in non-political voluntary associations breeds political involvement. People learn "civic skills" (such as how to participate in meetings or write letters), develop "civic virtues" (such as tolerance and dealing with diverging opinions), learn about what is happening in their neighbourhood and in the wider community, obtain political information, and are politically mobilized by their organizations (Verba et al. 1995, pp. 304-333). Warren (2001, pp. 70-93) distinguishes between:

(1) Developmental effects on individuals. Developing, forming, enhancing, and supporting capacities of individuals for self-governance: people involved in voluntary associations are supposed to develop (feelings of) political efficacy, political skills (the practical civic skills of Verba et al. 1995, but also abilities to recognize manipulation and to think strategically), civic virtues (a sense for the public interest, tolerance, reliability, readiness to participate), and critical skills (the ability to reflect upon one's own interests and identity).

(2) Public sphere effects. Constituting the social infrastructure of public spheres that provide information, develop agendas, test ideas, represent distinctions, and provide voice: the contributions of voluntary associations do not directly contribute to the civility of people, but might be important as conditions. Warren mentions public communication and deliberation of public concerns, representations of difference (in particular easily ignored interests), and representations of commonality (needs and interests of all people, advancing the common interest).

(3) Institutional effects. Supporting and enhancing institutions of democratic governance by providing political representation, enabling pressure and resistance, organizing collective actions, and serving as alternative venues for governance: representation (political input and agenda-setting), resistance (organizing countervailing power), subsidiarity (producing collective goods), and coordination and cooperation (creating trust between groups; organizing collective action).

Other theorists and researchers have presented similar lists of mechanisms. ${ }^{10}$

\footnotetext{
${ }^{10}$ Fung (2003) distinguishes six ways in which associations are presumed to enhance democracy: through the intrinsic value of associative life; by fostering civic virtues and teaching political skills; offering resistance to power and holding government accountable; improving the quality and equality of representation; facilitating public deliberation; and creating opportunities for citizens and groups to participate directly in governance.
} 


\section{Doubts about the Civilizing Effects of Civil Society}

The civicness of civil society has been elaborated in empirical analyses in recent years in several respects: in particular social trust, feelings of solidarity towards strangers, and political interest and involvement have been analyzed as possible (by)products of civil society activities. This has been done at the macro-level of territories, especially countries (countries with a larger and more active civil society should have higher levels of civicness in the sense of higher levels of social capital and public discourse), the meso-level of organizations (nonprofits show more civicness than state and commercial organizations), and at the micro-level (individuals involved in voluntary activities show more civicness than individuals who are not involved).

At the macro-level, various publications have shown positive statistical "effects" of the density of voluntary associations on national levels of social trust and political involvement, and on prosperity and the quality of political democracy (Putnam 1993). Putnam's comparative analysis of 20 Italian regions revealed that the performance of regional government was strongly tied in with the "degree of civic community." Civic community refers not only to individual characteristics such as reading newspapers, voting and organizational membership, but also to collective characteristics such as the presence of a dense network of social organizations, including a broad spectrum of organizations, ranging from trade unions through sports clubs to choirs. On the other hand, some economists have doubts due to rent-seeking interest groups that disturb competition and slow down growth (Olson 1982). Furthermore, there are some worrying political outcomes of vibrant associational life, from the Weimar Republic to Yugoslavia as "one of the most developed civil societies of any Eastern European country" (Chambers 2002, p. 101).

At the meso-level, it is difficult to make comparisons of "similar" organizations. Even when focused on service providers in the same field, problems of comparability and measurement steal the limelight of substantial results. The results do not overall suggest more civicness on the part of nonprofits (Flynn and Hodgkinson 2001; Hupe and Meijs 2002). At the micro-level, many researchers have worked on testing and retesting the conclusion of Almond and Verba (1989, p. 265) that "membership in some association, even if the individual does not consider the membership politically relevant and even if it does not involve his active participation, does lead to a more competent citizenry." For many countries, types of organizations, and forms of involvement reports are available about statistical relationships between participation in voluntary associations and indicators for social trust, pro-social attitudes, and political involvement (see, for instance, Dekker 2004; Putnam 2000, pp. 336-344). Across the board, the relationships are positive but modest, and not much evidence has been found for a causal relationship between voluntary associations and attitudes and political involvement.

Other research raises more doubts about the relevance of participation in voluntary associations for generating social capital and public discourse. To mention two findings: activities and volunteering are often not an extra stimulus to go beyond passive membership, and "mailing list" organizations do not show 
smaller effects than face-to-face organizations, although they offer hardly any opportunity to develop trust through interaction or political involvement through practice. These non-differences raise serious doubts about whether we really are seeing genuine effects of associating and not some result of self-selection (Sobieraj and White 2007). More generally, we may question the importance of direct causal mechanisms between involvement in voluntary associations and the alleged benefits of civil society: might it not be that involvement in associational life and in politics, social trust, and a positive attitude towards strangers are primarily different aspects of a particular kind of person? One can well image a common background of social and political involvement: "joiners," people who "want to make a difference", strong personalities, who have more opportunity to get involved in any area of life, etc.

Voluntary associations are supposed to be of special interest in relation to civicness because they bring together people from different social groups as citizens, in a more or less public setting. In this setting, they can develop general trust, broaden their perspectives, and discover issues of common interest. In reality, associations nowadays are often quite homogeneous (Theiss-Morse and Hibbing 2005) and often cover a very limited area of interest. The promotion of group interests can also lead to a narrowing of perspective and acting against the interests of the wider community (Bell 1998). A modern consumerist sports club is very different from the kind of voluntary associations De Tocqueville saw in America in the 1830s. They were often focused on community problems- "build schools, hospitals, and jails" - which acted as a natural bridge to politics. Voluntary associations were often multipurpose groups (looking after interests, socializing, and so on) with an important role in people's daily lives, more important than modern specialized organizations focusing on a specific interest or one leisure need. ${ }^{11}$ They are less important for people today, and the time spent in voluntary associations is generally very small compared to the many hours of paid work, study, family life, and informal socializing.

The majority of present-day voluntary associations are not the "schools of democracy" that De Tocqueville saw all those years ago. Organizations focusing on community affairs and interests that are related to government still show the expected relationships between associational and political involvement, but mainly as a result of self-selection. They are "pools of democracy" (Van der Meer and Van Ingen 2009).

Even for very dedicated forms of voluntary association, organizations, and groups of volunteers who deal with social issues, there are reasons to question their civicness. This is what Nina Eliasoph (1998, p. 63) found among a number of American groups:

Silencing public-inspirited political conversation was, paradoxically, volunteers' way of looking out for the common good. Volunteer work embodied, above all, an effort aimed at convincing themselves and others that the world

\footnotetext{
11 Skocpol (2003, p. 5) refers to the mentioning of the membership of voluntary associations on a gravestone of two centuries ago, and adds that it is unimaginable that her professional organization memberships will be mentioned on hers.
} 
makes sense, and that regular people really can make a difference. To show each other and their neighbors that regular citizens really can be effective, really can make a difference, volunteers tried to avoid issues that they considered "political." In their effort to be open and inclusive, to appeal to regular, unpretentious fellow citizens without discouraging them, they silenced public-spirited deliberation, working hard to keep public-spirited conversation backstage. ${ }^{12}$

Overall, then, there are good reasons to be sceptical about the civicness of civil society as a sphere of voluntary associations and volunteering (Edwards 2004, pp. 82ff; Theiss-Morse and Hibbing 2005).

\section{Crossing Borders and the Benefits of Hybrids}

Voluntary associational relationships are spreading in society, from negotiating in families to teamwork in business. Various developments suggest a kind of disappearance of civil society, with associations and activities becoming more business-like, boundaries blurring. These developments can often also be interpreted in a more positive way: associations are less important and more distant to individuals, but many more people are involved and people are members of more associations or are connected in other ways to advocacy and interest organizations. Ranged against the possible drawbacks of building less social trust and capital on a small scale are political benefits such as democratization and the stimulation of large-scale public debate.

Let us, then, turn to look at some phenomena which suggest an intermingling of roles and rationalities between civil society and the other spheres of society. For, in various segments of the third sector we are seeing the emergence of "hybrid" organizational types, in which commercial and nonprofit activities are combined and there is a simultaneous focus on meeting consumer demand and fulfilling social tasks (Brandsen et al. 2005; Dees and Anderson 2003; Evers 2005; Hupe and Meijs 2002). In a country such as The Netherlands, these are mainly formerly ideologically institutionalized and private-initiative organizations which grew in the context of the post-war welfare state, through a mix of subsidies, professionalization, and mergers, into fully fledged social service-providers. Here and elsewhere, commercial players have also begun operating in what have traditionally

\footnotetext{
${ }^{12}$ Another observer of the American scene has written that: "Setting government to the side of one's thinking may have become the condition for believing that civic involvement matters at all" (Wuthnow 1998, p. 57). Also consider the conclusion from a study of a group of Japanese housewives who helped disabled people: "The longer a woman participated in the volunteer world, the more likely she was to blame politics for social situations that she found unacceptable. Nevertheless, this blame seldom drove a volunteer to conclude that she must dedicate herself to changing the structure of politics and policy to eliminate those situations. Instead, she often remained committed to avoiding politics when possible. Volunteers spoke of the importance of individuals, of the world close to home, of "human networks", (LeBlanc 1999, p. 112). Of course, these findings do not rule out an overall positive statistical relationship between volunteering and political involvement. They do, however, cast doubt on the interpretation of this relationship as proof that "volunteering is part of the syndrome of good citizenship and political involvement" (Putnam 2000, p. 132).
} 
been nonprofit areas (insurance, consultancy), accepting that there are parts of their organizations which do not make a profit but which primarily serve social objectives.

A different example of commercial institutions entering areas that have been the traditional preserve of civil society is "the rise of third places" in America as a way of meeting the need on the part of "new consumers" for places where people who are relatively unknown to each other but who have shared interests can meet (Lewis and Bridger 2000, pp. 121ff). American examples of such "neither home nor work, neither completely private nor entirely public" (ibid., p. 122) third places include the opportunities to read and talk at the Barnes and Noble and Borders bookshops and the Starbucks coffee shop chain. These will not immediately become local centres for civic engagement, but there is also no reason to assume that they are any less relevant for lighter forms of voluntary association than more "mainstream" civil society organizations.

Conversely, we see the associational way of doing things moving from civil society into business life and state bureaucracies. Against the background of increasing knowledge intensity and complexity, the importance of voluntary commitment to organizational goals, voluntary cooperation, and voluntary initiative is growing across the board, including in business. Persuasiveness is becoming more important than having a formal say. Less abstract than the spread of associational coordination mechanisms in the workplace is the development of the workplace as a civilizing alternative to the voluntary association. Cynthia Estlund (2003) devotes extensive attention to this in her book Working Together, an allusion to Bowling Alone by Robert Putnam (2000), which carries the subtitle How Workplace Bonds Strengthen a Diverse Democracy. For the vast majority of people, the workplace (or, earlier than this, the educational establishment and much later perhaps the care institution) is much more important than a club or other voluntary leisure association for learning to get along with non-related fellow citizens, acknowledging common interests, developing relationships of trust, talking about social problems, and possibly debating political issues. In the world of work, people find it "necessary to get along and get things done with others with whom they would not otherwise choose to associate" (Estlund 2003, pp. 103-104). Clubs cannot compete with that, either in terms of the perceived need to find a solution together or in terms of the investment of time and diversity. Considerations of justice, equal rights, social responsibility, and the environment are probably more important in the average workplace than on the average sports field (see also Brandsen, this issue).

The recognition of broader responsibilities also lies at the core of "corporate social responsibility" (CSR). Whether introduced for tactical and public relations reasons or stemming from genuine concerns about the social and natural environment and future and distanced stakeholders, CSR forces a more inclusive justification of economic action and stimulates civilizing debates. In addition, philanthropic activities and employee volunteering will stimulate relationships between companies and organizations with a civil society background.

Political consumerism and consumer activism are also examples of civil society in the economy (Micheletti 2004). Instead of engaging in voluntary associations that develop political activities in civil society, individuals are beginning (not 
infrequently via the Internet) to take on a role as active consumers. They need not have an explicitly political or social purpose; they may also be focused on personal safety or health, for example, but in order to increase the effectiveness of their efforts, they focus their personal interests on collective organization and communication, and this takes the active consumer into the sphere of civil society. Consumer activism is a manifestation of a broader socialization and moralization of economic life (Shamir 2008). The idea of a market which operates on the basis of direct economic and material need is outmoded: buying and selling is increasingly about things such as anxieties, feelings of guilt, and considerations relating to honesty, authenticity, exclusivity, solidarity, and sustainability. All this removes economic transactions from the sphere of pure utility considerations and ethical indifference.

A final selection of examples of blurring boundaries and hybrid organizations concerns the relationships of volunteering and activist citizens with government, public administration, and (semi-)public service-providers. These providers organize voluntary work and turn the school playground, the care home, and the neighbourhood or services centre, into meeting places for citizens and opportunities to develop civic engagement (Evers 2005). The ties are probably looser and more functional than those between volunteers in traditional voluntary associations, but that is a benefit when mobilizing new groups and trying to build between groups with different cultures, ideologies, and lifestyles. The service-providers can also act as the infrastructure for social action in neighbourhoods and in a wider context (Sampson et al. 2005).

Local government appears to be an essential partner for the start and continuity of all kinds of "citizen initiatives." Recent research in The Netherlands suggests that pure citizen initiatives are the exception rather than the rule; institutions are normally involved from the start. It is not only their financial support and facilities that are important, but also supporting professionals and a positive and responsive attitude on the part of policymakers. This may have drawbacks in terms of dependency and too quickly limiting discussions and claims to what is politically feasible, but positive civilizing effects are plausible as well: to obtain public money and secure the ear of the authorities, active citizens will have to show that they are non-discriminatory, open to other groups, ready to put their own interests into the context of what is reasonable for the wider community, and willing to be publicly accountable etc. 'Organizations independent from government don't have a monoply on civic qualities' (Read 2006; cf. Bell 1998; Schudson 2006).

These kinds of effects prompt Eliasoph to call for a more positive appreciation of the inclusion of volunteers in public-private hybrids or "scrambled institutions" as opposed to the classic "avoiding politics" volunteer groups referred to earlier. Participants in hybrid organizations have to talk about politics and big issues of inequality and injustice in order to demonstrate why they need public support and to justify their actions publicly. Eliasoph's argument (this issue) about empowerment projects in the United States also discusses the drawbacks of volunteers as compared to professionals. The professionals in these projects appear to be more committed, caring, and respectful to the people to be served than the "plug-in" volunteers with their temporary and often amateurish activities. Sennett (2003, pp. 191) is also 


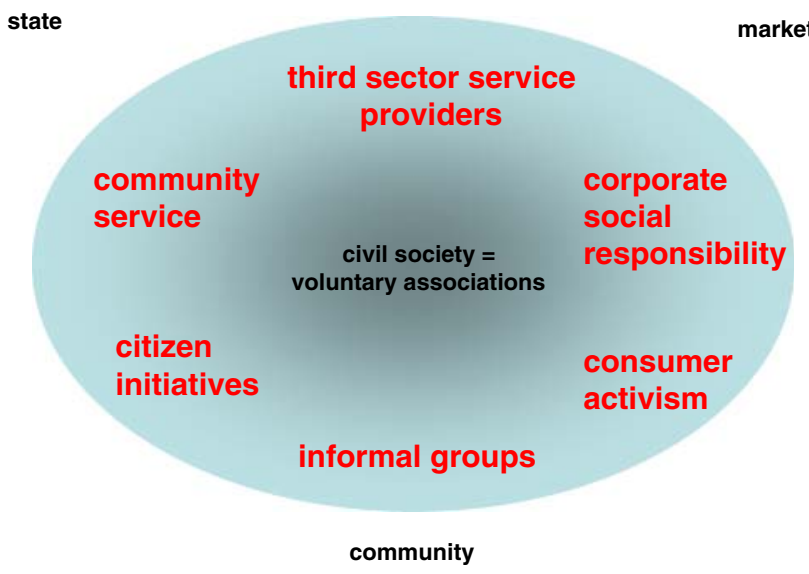

Fig. 2 The new debate: The dissolution of civil society and the blending of civicness

sceptical about volunteers and positive about professionals, basically because he prefers large-scale solidarity and considers voluntary support too personal. Behind this are considerations about respect for people in a dependent situation and about their own self-respect. These are big civility issues, but it is straying a little off the topic of hybrids, so we will leave this here for now.

The phenomena touched on here suggest a blurring of the boundaries between civil society and other spheres and a "dissolution of civil society" (Dekker 2004). Together they create a need to amend the portrayal of threats and fronts shown in Fig. 1 into one of intermingling and criss-crossing initiatives and organizations. Figure 2 is an attempt to represent this. Instead of polarities, it shows some hybrid forms in the margins of civil society. Civicness is no longer expected of a core of civil society that is absolutely not in the sphere of state and market (and community), but is expected from forms that blend voluntary involvement with the public accountability and equality principles of the state and the openness and efficiency of the market (and sources of affection and identity from the community). ${ }^{13}$

Different views can be taken on the blurring of the boundaries around civil society and the mingling of its characteristic voluntary associations with coordination mechanisms and perspectives of action from other spheres-here mainly the market/economic sphere with its matching of supply and demand and striving for profit. This has positive aspects and offers opportunities: the material basis of voluntary associations can be strengthened; effectiveness and efficiency can increase; commercialization and a stronger focus on the customer can reduce the

\footnotetext{
13 Community service and informal groups are not included in Fig. 2. I consider them as part of the dissolution of civil society, but as less relevant for the topic of civicness. Community service(s) combine public regulation and coercion with activities that traditionally belong to civil society. Informal groups (self-help and support groups, [Bible] reading groups, people regularly making music together, etc.) do similar things to voluntary associations, but in a less organized way and on a smaller scale, often as friends.
} 
self-satisfaction of club life; and the openness to new groups in society and their social needs can be increased.

Warren (2003) gives a more critical account of hybrids, or as he calls them, media-blended organizations. Warren mentions a number of dangers of the blending of normative means of associational organization or the third sector with the power of the state and the money of the market, including the exercise of public power without parallel responsibility to the public; inequity in the provision of public goods and services; and disturbances of representation of social and economic interest in the political sphere. As Warren (2001, p. 50) writes: "These are interesting dangers, however, because the blending is at the same time essential to the coordination among spheres in general, and crucial to... democratic functions of the nonprofit sector."

The following papers in this special issue of Voluntas focus further on hybrid social service organizations. These core institutions of modern welfare states are very interesting cases for discussing changes in the ideals of civility and civilizing interventions (Evers), the intra-organizational mixtures and contradictions over civility (Brandsen), and the diverse national and European policy orientations towards the roles of these organizations (Enjolras). Finally, though, I take a step back and return to the ideals of civility that might not materialize in this field.

\section{More Civicness}

I have argued that the basic civil society hypothesis that a separate civil society sphere of voluntary associations is of unique importance for achieving a more civilized society as a whole, is an idea that has been superseded. We would do better to focus on the civicness of the hybrids at the margins of the civil society sphere, or places where voluntary commitment and discursive coordination are imported into other spheres.

Civility is not, however, an automatic output of these hybrid forms. More than that, it is often not clear precisely what that output will be. As noted at the beginning of this paper, there are a number of very different meanings of civility in circulation. Where those meanings embrace politeness, courtesy, and respect, there will also often be a consensus between those concerned, or that consensus will be easily achieved. Things become more complex when it comes to active civility, concerned with the common good and political engagement-what might be expected as a contribution to Shils's notion of "substantive civility."

This active civility receives little attention in public opinion (see Table 1) and is surrounded by a kind of wall of silence, even on the part of the active citizens and volunteers who are supposed to contribute to it most. Based on qualitative research among volunteers by others and myself, I would like to raise two related concerns here. The first concern is that it is becoming more and more difficult to talk about the moral aspects of volunteering. The moralist communitarian Amitai Etzioni (2008) writes about "the denial of virtue." We live in somewhat cynical times in which motivations that do not derive from interests are suspicious; moral arguments sound at the least irrational or rather pathetic. 
In The Netherlands, for instance, older and above all religious people from the countryside may sometimes still talk about moral and religious duties, but young and modern people do not. Young people in particular seem to have problems explaining why they volunteer. They seem to want to avoid moral reasons; which they feel sound too feeble. "Why do you volunteer?"- "Somebody has to do it"; "because it is fun"; "because it was my turn"; "because I wanted to do something else"; or there is no answer at all, one "just does things." This moral silence might be related to a growing absence of explicitly political arguments. No more talking about dreams, no more controversies; "just do it."

This leads me to my second concern, which is that virtues that play a role in volunteering could become less and less civic virtues in relation to the political community, implying a growing inability to discuss ideological issues, take a stance in major controversies, or to relate to the remote and sometimes dirty world of politicians, bureaucrats, and interest groups. As various researchers have suggested, there is a possibility that we may find more and more deviations from the Tocquevillian pattern of broadening voluntary involvement, with social volunteering potentially evolving away from the classic issues of political participation.

Social scientists would also do well to ask themselves to what extent they are implicitly supporting processes that deny greater civic virtues and avoid the politics of voluntary involvement through their use of rational choice language and their inability to deal with virtues, values, and political aspirations in a disciplinary scientific way. It is interesting in this respect to consider Robert Putnam's intellectual development since his discovery of "civic community" (individually measured as voluntary association membership, newspaper readership, and political behaviour) in Italy (Putnam 1993) via "forms of social capital that, generally speaking, serve civic ends" to something that "just like any form of capital" can be used in a pleasant and an unpleasant way (Putnam 2000). This scientific neutralization has been a success in the sense that many more people are involved in social capital research than would ever have been drawn to research on the "civic community"; on the other hand, the price is that issues of civicness are ignored and left to politicians and priests.

Surely it is time for social researchers to return to the civic community and explicitly address the meaning of civicness. In present-day empirical participation research "civic involvement" often means nothing more than being not political. Examples of this not purely political participation are often noble, ${ }^{14}$ but at a theoretical level more profane leisure activities are not excluded and in fact these often constitute the mass of civic engagement activities measured by surveys. Lichterman (2005, p. 8) offers more focus by describing "civic groups" as: "groups in which people relate to each other and to the wider society primarily as citizens or members of society, rather than as subjects of state administration or as consumers,

\footnotetext{
14 "Political engagement is actively aimed at influencing government policies or affecting the selection of public officials... Civic engagement, on the other hand, refers to participation aimed at achieving a public good, but usually through direct hands-on work in cooperation with others. Civic engagement normally occurs within non-governmental organizations and rarely touches upon electoral politics. The most obvious example of this kind of participation is volunteer work in one's community" (Zukin et al. 2006, p. 51).
} 
producers, managers, or as owners in the marketplace. They relate to each other "civic-ally." This is not an operational definition to simply distinguish civic from non-civic groups, but it does direct the researcher's attention towards their inclusiveness and public orientation, and calls for a discussion of how various meanings of civility apply and interact.

Alexander (2006, pp. 92ff) goes a step further by replacing the all-embracing neo-Tocquevillian notion of a civil society of voluntary associations with a civil sphere of public-minded "civil associations" intertwined with communicative and regulatory institutions, such as polls and mass media, respectively, voting and positions of authority in government. Together they form a "solidarity sphere, in which a certain kind of universalizing community comes to be culturally defined and to some degree institutionally enforced" (Alexander 2006, p. 31). Civil associations express universalizing solidarity, have communicative intents, and have an interest in political power. The normative directedness of Alexander may be disputed and will not be easy to handle in empirical research, but he offers a challenging civicness perspective. The crisis that has manifested itself in the financial sector demonstrates at least the relevance of his sphere hybridity. Pressure for more civility in economic life seems to develop primarily in a dynamic process of public opinion, media, and politicians, with "civil-society organizations" playing only a minor role.

Open Access This article is distributed under the terms of the Creative Commons Attribution Noncommercial License which permits any noncommercial use, distribution, and reproduction in any medium, provided the original author(s) and source are credited.

\section{References}

Alexander, J. C. (2006). The civil sphere. Oxford: Oxford University Press.

Almond, G. A., \& Verba, S. (1989). The civic culture. Newbury Park: Sage.

Anheier, H. (2007). Reflections on the concept and measurement of global civil society. Voluntas, 18(1), $1-15$.

Banfield, E. C. (Ed.). (1992). Civility and citizenship in liberal democratic societies. New York: Paragon House.

Barber, B. R. (1998). A place for us. New York: Hill and Wang.

Bell, D. A. (1998). Civil society versus civic virtues. In A. Gutman (Ed.), Freedom of association (pp. 239-272). Princeton, NJ: Princeton University Press.

Billante, N., \& Saunders, P. (2002). Six questions about civility. Sydney: The Centre for Independent Studies (Occasional paper 82).

Boyd, R. (2006). The value of civility? Urban Studies, 43(5/6), 863-878.

Brandsen, T., van de Donk, W., \& Putters, K. (2005). Griffins or chameleons? International Journal of Public Administration, 28(9/10), 749-765.

Carter, S. L. (1998). Civility. New York: Basic Books.

Chambers, S. (2002). A critical theory of civil society. In S. Chambers \& W. Kymlicka (Eds.), Alternative conceptions of civil society (pp. 90-110). Princeton, NJ: Princeton University Press.

Cohen, J., \& Arato, A. (1992). Civil society and political theory. Cambridge, MA: MIT Press.

De Tocqueville, A. (1990). Democracy in America (Vol. 1 and 2). New York: Vintage Books.

Dees, J. G., \& Anderson, B. B. (2003). Sector-bending. Society, 2003(5/6), 16-27.

Dekker, P. (2004). The sphere of voluntary associations and the ideals of civil society. Korea Observer, 35(3), 391-415. 
Dekker, P. (2008). Civic virtues and volunteering in Europe. Paper for the contemporary perspectives on volunteering conference at Ersta Sköndal Högskola, Stockholm, 10-12 September, available online: http://cinefogo.cuni.cz/. Accessed June 2009.

Edwards, M. (2004). Civil society. Cambridge: Polity Press.

Eliasoph, N. (1998). Avoiding politics. Cambridge: Cambridge University Press.

Estlund, C. (2003). Working together. Oxford: Oxford University Press.

Etzioni, A. (2008). The denial of virtue. Society, 45(1), 12-19.

Evers, A. (2005). Mixed welfare systems and hybrid organizations. International Journal of Public Administration, 28(9/10), 737-748.

Flynn, P., \& Hodgkinson, V. A. (Eds.). (2001). Measuring the impact of the nonprofit sector. New York: Kluwer Academic/Plenum.

Fung, A. (2003). Associations and democracy. Annual Review of Sociology, 29, 515-539.

Hupe, P. L., \& Meijs, L. C. P. M. (with M. H. Vorthoren). (2002). Hybrid governance.The Hague: The Netherlands Institute for Social Research/SCP.

Keane, J. (1998). Civil society. Cambridge: Polity Press.

LeBlanc, R. M. (1999). Bicycle citizens. Berkeley: University of California Press.

Lewis, D., \& Bridger, D. (2000). The soul of the new consumer. London: Nicholas Brealey.

Lichterman, P. (2005). Elusive togetherness. Princeton, NJ: Princeton University Press.

Margalit, A. (1996). The decent society. Cambridge, MA: Harvard University Press.

Micheletti, M. (2004). Political virtue and shopping. New York: Palgrave.

Mouritsen, P. (2003). What's the civil in civil society? Political Studies, 51(4), 650-668.

Mutz, D. (2006). Hearing the other side. Cambridge: Cambridge University Press.

Olson, M. (1982). The rise and decline of nations. New Haven: Yale University Press.

Putnam, R. D. (with R. Leonardi and R. Y. Nanetti). (1993). Making democracy work. Princeton, NJ, Princeton University Press.

Putnam, R. D. (2000). Bowling alone. New York: Simon \& Schuster.

Pye, L. W. (1999). Civility, social capital, and civil society. Journal of Interdisciplinary History, 29(4), $763-782$.

Read, B. L. (2006). Rethinking the civic properties of state-lined associations. Democracy \& Society, 4(1), 12-14.

Sampson, R. J., McAdam, D., MacIndoe, H., \& Weffer-Elizondo, S. (2005). Civil society reconsidered. American Journal of Sociology, 111(3), 673-714.

Schudson, M. (2006). The varieties of civic experience. Citizenship Studies, 10(5), 591-606.

Sennett, R. (2003). Respect in a world of inequality. New York: Norton.

Shamir, R. (2008). The age of responsibilization. Economy and Society, 37(1), 1-19.

Shils, E. (S. Grosby, Ed.). (1997). The virtue of civility. Indianapolis: Liberty Fund.

Sistare, C. T. (Ed.). (2004). Civility and its discontents. Lawrence: University Press of Kansas.

Skocpol, T. (2003). Diminished democracy. Norman: University of Oklahoma Press.

Sobieraj, S., \& White, D. (2007). Could civic engagement reproduce political inequality? In S. A. Ostrander \& K. E. Portney (Eds.), Acting civically (pp. 92-110). Medford: Tufts University Press.

Taylor, C. (2003). Modes of civil society. In C. M. Elliott (Ed.), Civil society and democracy (pp. 43-62). New Delhi: Oxford University Press.

Theiss-Morse, E., \& Hibbing, J. R. (2005). Citizenship and civic engagement. Annual Review of Political Science, 8, 227-249.

Van der Meer, T. W. G., \& Van Ingen, E. J. (2009). Schools of democracy? European Journal of Political Research, 48(2), 281-308.

Verba, S., Lehman Schlozman, K., \& Brady, H. E. (1995). Voice and equality. Cambridge, MA: Harvard University Press.

Walzer, M. (1974). Civility and civic virtue in contemporary America. Social Research, 41(4), 593-611.

Warren, M. E. (2001). Democracy and association. Princeton, NJ: Princeton University Press.

Warren, M. E. (2003). The political role of nonprofits in a democracy. Society, 40(4), 46-51.

White, M. (2006). An ambivalent civility. Canadian Journal of Sociology, 31(4), 445-460.

Wuthnow, R. (1998). Loose connections. Cambridge, MA: Harvard University Press.

Zukin, C., Keeter, S., Andolina, M., Jenkins, K., \& Delli Carpini, M. X. (2006). A new engagement? New York: Oxford University Press. 